\title{
Biblical Text On the Work of "Meshari" (Missal) by Gjon Buzuku
}

\author{
Sarë Gjergji, PhD Cand.
}

\begin{abstract}
Vepra "Meshari" e Gjon Buzukut, me kohë është bërë objekt studimi i studiuesve të ndryshëm, të cilët nisur nga përmbajtja fetare e veprës, nga prania e tekstit biblik në të, veprës, në të shumtën e herëve, i mohojnë vlerat letrare, duke e parë atë vetëm në aspektin gjuhësor. There are still some scholars who doubt or deny the presence of the subject matter in this work. Even when is discerned as the literary work, still continues to be seen with suspicion as such. In this case our interest will not be the language of the literature work aspect of Missal, but to argue by means of facts of its content of literary aspect. Through this work it will prove to be clarified whether the Missal is a literary work or not.
\end{abstract}

Keywords: Bible literature, book, literary type, psalms, literary work.

\section{Introduction}

The object of our examination is the literary works of John Buzuku, Missal, which is published in 1555. The first pages of the book are missing, therefore there is no knowledge of publication place. It is only known as the first works published in Albanian Language.

In the Biblical books intertwined are genres, different kinds of style, from epic and Romanesque, up to those with sentences, dramatic and lyrical. The Bible has continued and continues today to nurture authors with the material for their works of numerous fields of art and knowledge. Since the Buzuku's Missal consists of various literary Biblical texts, such a characteristic, anyways, we have encountered it in this act.

As we shall see in continuance, the presence of different kinds of literary works of Buzuku, proves the value of undeniable literary work in question on the one hand, and the contribution of the author as a writer for the inclusion of various types of literature in Albanian literature, on the other hand. Evidencing multiple parts and the highlights that from which biblical books were taken, make it more acceptable the literar dimension of Missal for those who refuse literacy of this literary work.

\section{Promotion for the Establishment of the Literary Work in Albanian Language}

In the writing and creation of works, according to today's recognition criteria, we can call them of early Albanian writings and works (XVII-th century), in addition to numerous internal motives, subjective (of their authors), and numerous motives , external, objective, a very important stimulating role, have played principles, advices, lessons, messages and different Biblical ideas, which Illyrian-Albanian ethnos, as is known, has had early and many contacts for long centuries.

The Biblical literature, in the early days of the albanian language writings, was the main literature, the basic literature of writers and intellectuals and the literature with the major influence of Albanian scripture and creativity. The impact of this literature is very natural by the ancient Albanians writers, when we consider their religious mission they had, who had grounding knowledge of biblical texts, as evidenced by the recognition of ideas, principles, teachings and the Biblical counseling in their writings, and their attempt to provide the Bible in Albanian Language. In this context, should also see John Buzuku as such, the author of Missal work (1555). Buzuku,as it proves itself in the afterword of the book, has made the work out of love for the country and for the language, and for the lack of the scriptures in the Albanian language and that, as required by biblical Enlightenment, through the script in Albanian in order to enlighten minds to them who would listen. ${ }^{1}$ The work integrates literature, philosophy, religion, politics and the Albanian national ideology. Religious themes of the Missal at the same time is a political topic. The idea of creating such a work presents, at the same time, the national

${ }^{1}$ Buzuku, Meshari, botim kritik i punuar nga Eqrem Çabej, Universiteti Shtetëror I Tiranës - Instituti i Historisë e i Gjuhësisë, Tiranë, 1968, 292; Buzuku, Meshari, botim kritik i punuar nga Eqrem Çabej, Rilindja, Prishtinë, 1988, 387. 
idea, since then, as I.Rugova has said that, religious idea has presented even the national idea. ${ }^{1}$ In this context, Buzuku has classified it as a sin if an Albanian becomes a Turk, ${ }^{2}$ which means to convert to the belief that was carried by the conqueror, by the Ottoman Empire. Work as such, with the text of the biblical dimension that expresses ideological conflicts, religious and cultural, including political conflict, of ethnic Albanian world with foreign ones, as of the Ottomans.

\section{Literary Types (Biblical) in Missal Work}

Must be said that Missal is a work consisting of a series of biblical texts, liturgical texts of prayers, litanies and rituals. ${ }^{3}$ The texts included in the book are not always translations, but there are adaptations and deliberate avoidances of the original text (Latin), ${ }^{4}$ as well as original pieces, then texts which are drawn by Buzuku in the form of prayer-the blessings, anthem, which by way of expressing of the treated object may approach Psalms, and can be taken as poetry. ${ }^{5}$ Here, we must not forget either the Afterword of the book, with which are provided the first signs of prose in Albanian literature, written in the Biblical style. Buzuku makes the selection of texts in order to fulfill purposes for religious services and also to educate the believers. Functioning and experience of the Missal as a literary work, scholar Zeqirja Neziri sees it in analogy with the literature textbooks, literature reading books. ${ }^{6}$ Both are written for institutional practical purposes, but to serve to the literature. In fact, in the Middle Ages all forms of life were intertwined with religiosity. Middle Ages represents one of those historical moments when a "text to be perceived aesthetically, there should be a function (for example, political, religious) except that of aesthetic. ${ }^{7}$

Missal known for the diversity of literary creations. Buzuku has included in it creations from various types of Bible books, which differ in form, content, style, figuration, metaphors and literary types and under usual division, are divided into historical books, wisdom books, prophetic books, religious poetry etc.

From the type of historical books, Buzuku in his work has included creation of numerous literary, as the Book of Genesis (Genesis), the Book of Exodus, of Leviticus, from the Book of Numbers, the book of Deuteronomy, the Book of first and second Kings, the second book of Maccabees, from the Gospel of Matthew, Mark, Luke, John and Acts of Apostles.

From the prophetic books, Buzuku has given enough in his literary creations, such as books of: Isaiah, Jeremiah, Daniell, Oziel, Joel, Amos, Jonah, Micah, Zechariah, Malachi and Revelation of John.

In Missal we have kinds of literature, such as: religious history, the history of salvation or redemption, the story of the apostles, epistolarin, type of work Esther (advices arising from history), Bible poetry (Psalms), prophesying literature, literature of apocalypse, literature of wisdom, myth, legend, tale, allegory, the story, the kind of didactic teaching creations, diary, polemical writing; different kinds of poetry, as a hymn, prayer, thanksgiving, patriotic poetry, meditative poetry,love poetry, poem, etc.

The Religious history, like the biblical literary genre, is very present in the work of Buzuku. Creations of this literary kind, Buzuku gives out of the Bible books as of: Book of Genesis, Exodus, of Leviticus, from the Book of Numbers, and Deuteronomy, the Book of First and Second Kings, etc., which by literary type is considered as religious history, that biblical scholars like to call it the history of redemption..$^{8}$ Of particular importance are the letters of the Apostles in the work of Buzuku, especially Paul's letter to the Romans, which is part of the most remarkable works of world literature and which simultaneously deals with the issue of human faith and the nobility of his, ${ }^{9}$ but also of Paul's letters occupy plenty of space in Missal, as well as the First Letter of John, in which, Buzuku has done his work.

\footnotetext{
1 Ibrahim Rugova, "Katër urata origjinale të Buzukut", Rilindja, Prishtinë, 24-25 tetor 1987, 12.

2 Buzuku, Meshari, Rilindja, Prishtinë, 1988, XXIII

${ }^{3}$ See: Eqrem Çabej, Historia e librit dhe lënda e tij. Hyrje e veprës: Meshari Gjon Buzukut(1555)1, Rilindja, Prishtinë, $1978,9$.

${ }^{4}$ See: Selman Riza, Vepra 4, Akademia e Shkencave dhe e Arteve e Kosovës, Prishtinë, 2004, 272.

${ }^{5}$ Anton Nikë Berisha, "Meshari"- vepër e hartuar nga Gjon Buzuku, Comet Editor Press,Cosenza, 2014, 21.

${ }^{6}$ See: Zeqirja Neziri, Meshari i Buzukut, Logos-5, Shkup, 2006, 110-111.

7 See: Jurij M.Lotman, Struktura umetnickog teksta, Nolit, Beograd, 1976, 110-111. And: Anton Berishaj, Letërsia performative Buzuku, Prishtinë, 2010, 12-13.

${ }^{8}$ Bible, Përktheu dhe shtjelloi Dom Simon Filipaj, Konferneca Ipeshkvore e Shqipërisë, Tiranë, 2011, 16.

9 Biblija - Stari I Novi Zavjet, Krscanska Sadasnjost, Zagreb, 1974, 119.
} 
Buzuku, also, in his work, has included literary creations from the Book of Wisdom, the Book of Job, the Book of Proverbs, the Book of Siracid, Book Song of Songs and the Book of Psalms.

Buzuku in his poetic creations includes Book of Isaiah (35:1-6) ${ }^{1}$, whose creations are regarded as magnificent poetic creations $^{2}$ and the most beautiful pages of the Old Testament, from The Book of Genesis (27:6-39, in Missal pg. XLIX/2), then from The Book of Ecclesiastes, where we have personal prayers of Buzuku, always with a pre-biblical text (2:18-21, LXXXV=CV etc.).

In general the work of poetic creations of Missal, as examples of love poetry have excerpts from world poetry of masterpiece of love, from work Song of Songs (6:10, IX/2; 2:8-14, LXXXVII=LXXXXVII, 11 E 10 XII ), Hymn of love (1 Corinthians 13: $1-13, X L / 2$ ), the poetic quality valued as precious as a pearl of world literature, lyrics of parental love and pain (the pain and love of Isaac, Genesis 27: 6-39, XLIX/2) etc..

In Missal work are encountered even some other literary creations from the other main type of biblical literature (known especially in the Old Testament) - the literature of apocalypse. Chosen creations of this kind of literary, Buzuku has given from the book Prophecy of Daniel, which is also considered the first biblical book of apocalypse ${ }^{3}$, but also from book The prophecy of Ezekiel and from the Revelation of John.

In Missal the myth is also present as literary kind. Buzuku in his works brings myth for creation of the world (Book of Genesis 1: 1-31, LIX / 2); the myth of Noas salvation (Genesis 7: 1-24, 8: 1-21, LX) and other of myths, like that has brought the legends and tales as literary types, but the allegory as a literary kind in the Bible. ${ }^{4}$

Narration as a literary genre, it is also present in the work of Buzuku. He has given a story Joseph and his brothers (Genesis 37:6-22, XLVIII), then the didactic story of Prodigal Son (The Gospel according to Luke 15:11-32, L) and other stories. Here's an excerpt of the story on prodigal son, which shows a rich literary system and the expressive style in Albanian language:

Buzuku: ${ }^{5}$ (for comparison, the translation of Dom Simon Filipaj):

Një njeri pat dy bij; e i tha mā i riu përindit: Atë, amë pjesënë qish më përket $n$ gjajet. E mbas jo shumë dit, mbëjledhunë qi pat gjithë kafshëtë, biri mā i riu vote tue shtektuom ndë dhē të largë, e përafroi të pasunitë e ti, tue ecunë pr udhë të pāglanë. E tue pasunë sosunë gjithë gjānë, u bā u e madhe nd atë dhē, e aj zu me ardhunë ndë të madhe nevojë. E u afëruo njëj bujari së qytetsë $s$ ati dheu. E aj e dërgoi ndë katund të ti me kullotunë thitë. E dëshir kish barkëtë e ti me e nginjunë n ledinjet qi thitë kullosjninë; e askush gjā nukë i ep. Ashtu u kujtuo ndë vetëhenë e tha: Sã trima të tim et kanë bukë tepërë, e u vdes uni! Qisht të banj u tash? U nçonem e vete tek em atë, e i thom: Atë, u rāe ndë kat mbë qiellt e përpara faqesë sate; e mā u nukë jam i denjë me u grishunë biri uit; përzemë porsi një $n$ trimashit së tūsh. $E$ si u ngriti, vote tek $i$ ati.

Luke, 15:11-20: "There was a man who had two sons. The younger one said to his father: "Father, give me my share of the estate. So he divided his property to them. Not long after that, the younger son got together all he had, set off for a distant country and there squandered his wealthd in wild living. After he had spent everything, there was a severe famine in that whole country, and he began to be in need. So he went and hired himself out to a citizen of that country, who sent him to his fields to feed pigs. He longed to fill his stomach with the pods that the pigs were eating, but no one gave him anything. When he came to his senses, he said, 'How many of my father's hired servants have food to spare, and here I am starving to death! I will set out and go back to my father and say to him: Father, I have sinnedf against heaven and against you! I am no longer worthy to be called your son; accept me as one of your hired servants!-So he then went to his father.'6

\footnotetext{
1 Buzuku, cited works., XXXII.

${ }^{2}$ Historia e letërsisë botërore 1, Rilindja, Prishtinë, 1987, 71.

${ }^{3}$ Historia..., 80.

${ }^{4}$ Nuhi Ismalji, Vepra e Gjon Buzukut, Ars Clubi "Beqir Musliu”, Gjilan, 2010, 43.

${ }^{5}$ Buzuku, cited works., L, 149

${ }^{6}$ Bibla, Dom Simon Filipaj, ..., 1286.
} 
In the Missal we have texts from the Book of Esther as is text 4:17 (c-17I, XLVII/2), which some historians call it the novel. ${ }^{1}$ Scholar Femi Cakolli, sees Missal as a liturgical novel, in which are found fragments from the main parts of Bible ${ }^{2}$

Even the proverb as a literary genre is not missing in this work, as we have present the example of poem, through the presentation of text from Job 1:21 and 2:1-10 (LXXXX), and the other texts of the evangelists.

\title{
Psalms in the Missal
}

In verses of creations of poetic work of Missal, we have different kinds of lyric poetry. So then in this work we discern pure poetry - the psalms.

From the Book of Psalms, Buzuku in his work has included enough psalms and psalm passages, among others: a). Psalm prayers - or complaint, or a psalm of mourning as: Psalm 6:2-11, XVI (Call for help when in trouble); 32:1-11, XVI/2 (Who admits sins, God frees them from the sins); 69:2-6, XIX (Pleading for help); 120:1-7, X/2 (Enemies of peace); 124:1-8, .XI (Savior of Israel); 129:1-8, XIII, XVII/2 (Against the enemies of Sion); 131:1-3, XIII (The spirit of childhood); 138:1-8, XX (Hymns of thanksgiving); 143:1-12,.XVII/2 (A prayer of humble; b).Hymns of glory, psalms: 85:2-14, IX/2 (Prayer for peace); 116:1-9, XIX/2, X/2 (Praises); 146:2-10, XX/2 (Hymn to the helping Lord), as the c). Psalms of thanksgiving: 116:1-2, IX/2 (Thanksgiving); 129:1-8, XIII, XVII/; psalm (with prophetic elements) 50:3-21, XVII.

From the examples of meditative poetry in the work are involved and the Psalms: 37:2-23, XVI/2; 119:1-7, XX. Examples of patriotic poetry we have psalms as: 121:1-7 (The Keepers of Israel), X/2; 125:1-5 (God protects his own), XI; 126:1-6, XI/2, XII ( Repatriation song); 127:1-6, XI/2 (Submission of providence); 128:1-6, XI/2 (Blessing-gift for the believer).

Psalm 130 (Hope in God), we find it translated in three variants at work of Buzuku and that on pages XIII, XVII, XX. Translation in three variants of this psalm, as the repetition of certain prayers, the author would have made for style issues. According to the researcher Anton Berisha, however, Buzuku with this psalm imposes two essential things: to save lives, and

a) individual repentance for the evil acts done and call for God from the depths of the soul to forgive sins, namely

b) trust of the chosen people, to Israel, in God to help and release from evil. The people of Israel expect God in supplication and more anxious than night watchman awaiting the dawn (very rare and semantic comparison).

As such psalm had great and of multiple importance for every Albanian believer, and all the Albanian people, who are suffering under the Ottoman slavery. This deep correlation of the fate of the chosen people to the fate of the Albanian people, was done also by other Albanian authors after Buzuku. ${ }^{3}$

That to the Missal of Buzuku, does not lack artistic literary values shows four original poems of Buzuku, which inspire even the literary and aesthetic experiences. They are written with inspiration, imitating the excellent Solomonic style. ${ }^{4}$ Here is one of them:

\author{
$O$ God of the living and the dead \\ savior of all who would not die or sinning, \\ make me change for the better and to live, feel me, \\ I beg you, take me John Buzuku closer, \\ destroy all my said sins \\ I you delight, hear my prayer.
}

\footnotetext{
${ }^{1}$ Historia e letërsisë..., 78.

2 Femi Cakolli, Kodi biblik në letërsinë shqiptare, Tenda, Prishtinë, 2003, 81.

${ }^{3}$ Anton Nikë Berisha, cited works, 59

${ }^{4}$ Moikom Zeqo, Vepra e Buzukut në rrafshin poetik dhe estetik, www. http://letersia.zemrashqiptare.net
} 
Lord for me and for all the people of my blood,

to my all friends and to my enemies,

for the living and for the dead. Amen!

O zot $\mathrm{i}$ të gjallëve dhe $\mathrm{i}$ të vdekurve

shpëtues i të gjithëve që s'do vdekjen e mëkatimet,

më bëj të ndryshoj për mirë e të jetojë, ndjemë,

të lutem ty, afromë mua, Gjon Buzukun,

m’i prish të shkruarit e tërë mëkateve,

se unë ty të pëlqej, dëgjo lutjet e mia.

Zot për mua e për gjithë njerëzit e gjakut tim,

për miqtë e mi e për armiqtë e mi,

për të gjallët si dhe për të vdekurit. Amen! ${ }^{1}$

\section{Conclusion}

Works of Buzuku, having in mind the time and circumstances when it was written and published, exceeds the limits of a typical missal, simply for the liturgical needs, as it is considered so far. It is beyond this domain, beyond this context. The texts (fragments) in prose and in poetry texts, which we receive them time to time and in more than one variant and repeated in the book, and explanatory text with afterword or presenting author at the end of the book, take Buzuku as a consciously creative author and a talented poet full of inspiration. ${ }^{2}$

Taking into count the linguistic-stylistic richness of the biblical text, what are the texts of Missal and accepting the Bible as a literary text, as as the Literature over of all Literatures, where the Missal is fed from, this work in the future should be treated and accepted as a literary text.

\section{References}

Berishaj, Anton, Letërsia performative Buzuku, Prishtinë, 2010.

Berisha N., Anton, "Meshari"- vepër e hartuar nga Gjon Buzuku, Comet Editor Press,Cosenza, 2014.

Biblija - Stari I Novi Zavjet, Krscanska Sadasnjost, Zagreb, 1974.

Bible, Përktheu dhe shtjelloi Dom Simon Filipaj, Konferneca Ipeshkvore e Shqipërisë, Tiranë, 2011.

Buzuku, Meshari, botim kritik i punuar nga Eqrem Çabej, Universiteti Shtetëror I Tiranës - Instituti i Historisë e i Gjuhësisë, Tiranë, 1968.

Buzuku, Meshari, botim kritik i punuar nga Eqrem Çabej, Rilindja, Prishtinë, 1988.

Cakolli, Femi, Kodi biblik në letërsinë shqiptare, Tenda, Prishtinë, 2003.

Çabej, Eqrem, Historia e librit dhe lënda e tij. Hyrje e veprës: Meshari Gjon Buzukut(1555) 1, Rilindja, Prishtinë, 1978.

Group of authors, Historia e letërsisë botërore 1, Rilindja, Prishtinë, 1987.

${ }^{1}$ Buzuku, cited works, XIX/2.

${ }^{2}$ See: Engjëll Sedaj, Shqipja arbërore, Scientific Foundation Dardani Sacra, Prishtinë, 2002, 135. 
Ismalji, Nuhi, Vepra e Gjon Buzukut, Ars Clubi "Beqir Musliu”, Gjilan, 2010.

Neziri, Zeqirja, Meshari i Buzukut, Logos-5, Shkup. 2006.

Lotman M., Jurij, Struktura umetnickog teksta, Nolit, Beograd, 1976.

http://letersia.zemrashqiptare.net

Riza, Selman, Vepra 4, Akademia e Shkencave dhe e Arteve e Kosovës, Prishtinë, 2004.

Rugova, Ibrahim, "Katër urata origjinale të Buzukut", Rilindja, Prishtinë, 24-25 tetor 1987.

Sedaj, Engjëll, Shqipja arbërore, Scientific Foundation Dardani Sacra, Prishtinë, 2002.

Zeqo, Moikom, Vepra e Buzukut në rrafshin poetik dhe estetik, www. 